The current issue and full text archive of this journal is available on AFEBI Management and Business Review at:

https://journal.afebi.org/index.php/ambr/article/view/503

THE INFLUENCE OF MOTIVATION, WORKING ENVIRONMENT AND CAREER DEVELOPMENT TOWARD EMPLOYEES' LOYALTY

\author{
Nada Fadhila, Endang Sulistyani* \\ Business Administration Department, Politeknik Negeri Semarang, Indonesia
}

\begin{abstract}
This research aims to determine the effect of motivation, working environment, and career development toward employees' loyalty at the PT Tawada Healthcare Semarang, which is one of the regional offices of PT Tawada Healthcare. PT Tawada Healthcare Semarang Branch is one of PT Tawada Healthcare office branch, a company engaged in medical devices provider that has been established since 1999. PT Tawada Healthcare has 13 branches throughout Indonesia and also provides medical devices in many hospitals in Indonesia. The data collection method used in this research are questionnaires, literature study, and interview. Sampling method used census. The sample are all population who are 35 data. The methods of data analysis used is Multiple Linear Regression, goodnes s of fit regression equation used are coefficient of determination, and $\mathrm{T}$ test. The results of this research shows that motivation, working environment, and career development have positive and significant influence on employees' loyalty. Working environment has a dominant influence in increasing employee loyalty.
\end{abstract}

Keywords: Career Development, Employees’ Loyalty, Motivation, Working Environment.

The Influence of Motivation, Working

Environment and Career

Development Toward Employees' Loyalty

Received

October $20^{\text {th }} 2021$

Review

Desember $20^{\text {th }} 2021$

Publish

December $31^{\text {st }} 2021$

*Corresponding author. Email address: endangsulis15@polines.ac.id

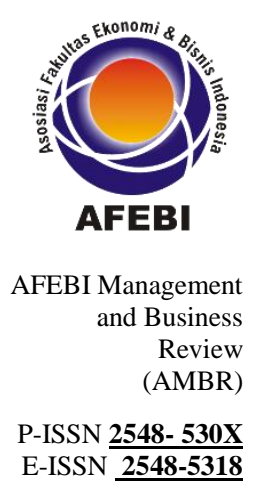


In this era of technological development, the field of health services increasingly needs very sophisticated tools to provide the best service for patients. The medical devices also need to be elevated in line with the advancement of the technology and the needs of the patients as well. Therefore, this kind of situation produces very competitive competition. Thus, to be able to survive in the competition, the company is required to always develop itself in order to win in the competition and achieve its goals in this era of competitive competition. Human is the most valuable and most important asset that is owned by an organization because the success of the organization is determined by the human resources Ardana et al. (2012).

The contribution which is required for a company from its employees is not only in the form of energy contributions but also conceptual contribution and employees' loyalty to the company. Loyalty should be measured by how much thought, attention, ideas, and dedication an employee puts into the job. Now employee loyalty is no longer just an employee's ability to complete their duties and obligations in accordance with the job description, but also how employees carry out their duties as optimally as possible to get the best results for the company. The definition of employees' loyalty by Becker et al. (1995) supports this; it can be defined as a strong desire to maintain a member of an organization, a willingness to perform high efforts for the sake of the organization, and a belief in and admissibility of the values and goals of the organization. Allen and Grisaffe (2001) explain that loyalty is a psychological state which can characterize the relationship of an employee with the organization and that it affects their decision to stay with the organization. Companies can give salary to an employee, but not necessarily be able to buy loyalty.

There are many factors that make an employee can become loyal, such as the working environment, compensation, effective communication, motivation provided by the company, a comfortable workplace, career development, procurement of employee training and education, work participation, implementation of occupational health and safety as well as the relationship between superiors and subordinates and employee relationships with each other (Susanto in (Purba and Andri 2017). Every organization wants to achieve its goals. To move people to conform to what the organization wants, it must be understood the motivation of humans working in the organization. Work motivation is an internal state that leads to the effort expended by a person towards goals and activities undertaken to encourage someone to complete work (Dubrin 2015). The research that conducted by Citra (2019) stated that motivation had a positive and significant effect to employees' loyalty.

Another factor that can make employees loyal to the company is the existence of a safe and comfortable working environment. A place where employees perform it works is called a working environment. Working environment consists of physical working environment and non-physical working environment (Sedarmayanti 2011). The spirit and passion of employees' work in carrying out work is influenced by many factors of the work environment. To achieve its result, working environment can bring positive or negative effect (Juliarti et al. 2018). Based on the research of Susita et al. (2020). Working Environment has a positive and significant effect on Employee Loyalty

Another encouragement that should be given to employees is career development. Career development is not only oriented to the company's goals but also to improve the ability, competence, and self-development of employees. Career development is a process in achieving individual work performance in achieving a future plan. Mangkunegara in (Utami and Dwiatmadja 2020) explains that career development is a work process that aims at career planning of employees within the company and relates to individuals in self-development. Every employee must be allowed to develop his career, namely as a tool to maintain the loyalty of every employee. Career development can also foster a commitment to employees. Purnamasari and Sintaasih (2019), who said that career development had a positive and significant effect on employees' loyalty.

PT Tawada Healthcare is a company engaged in medical devices provider that has been established since 1999. PT Tawada Healthcare has 13 branches throughout Indonesia and also provides medical devices in many hospitals in Indonesia. Due to PT Tawada Healthcare is engaged in the supplier of medical devices, marketing activities are one of the main supports for the company. Employee loyalty is needed because to achieve sales targets, employees need to give time, energy to build trusting relationships with customers and attract them to buy their products. There are still many employees who feel unsatisfied. This is proven by the employees' turnover rate in past 5 years.

There is a fluctuating employee turnover at PT Tawada Healthcare Semarang from 2016 to 2020. The turnover rate of PT Tawada Healthcare Semarang is always above 5\% and the highest is in pandemic era in 2020 which is reach more than $10 \%$ and it is categorized as high. From the pre-research interviews, employees who resigned because some of them were accepted in other companies with higher position and some were expelled for violating company's regulations. 


\begin{tabular}{|c|c|c|c|}
\hline Year & $\begin{array}{c}\text { Employees out } \\
\text { (person) }\end{array}$ & $\begin{array}{c}\text { Average Number of } \\
\text { Employee (person) }\end{array}$ & Turnover (\%) \\
\hline 2016 & 3 & 38 & 7.89 \\
\hline 2017 & 3 & 39 & 7.69 \\
\hline 2018 & 4 & 36 & 11.1 \\
\hline 2019 & 3 & 37 & 8.1 \\
\hline 2020 & 5 & 38 & 13.15 \\
\hline
\end{tabular}

The Influence of Motivation, Working

Environment

and Career

Development

Toward

Source: PT Tawada Healthcare Semarang, 2021

Employees'

Loyalty

Those phenomena above can be seen that the loyalty of employees of Tawada Healthcare Semarang has decreased. Companies need to give encouragement to employees and give more attention to the needs of employees so that they are more enthusiastic and passionate in their work. Some of the encouragement that can be given by the company to maintain the loyalty of its employees are in the form of giving motivation, providing a comfortable working environment for its employees, and also providing career development programs.

Based on those problems description then the research problems can be asked as follows:

a. How is the effect of motivation toward employees' loyalty?

b. How is the effect of work environment toward employees' loyalty?

c. How is the effect of career development toward employees' loyalty?

Table 1.

Employes'

Turnover Data at

PT Tawada

Healthcare

Semarang

\section{LITELATURE REVIEW}

\section{Employees' Loyalty}

Employees' loyalty is compliance committed by employees to the organization where he works, in which there is obedience and responsibility and strive to provide the best service and behaviour (Onsardi 2017). Loyalty is individuals' willingness to continuously identify organizational goals and objectives, believing in the organization's values and principles without questioning (Sazkaya and Dede 2018). Employees' loyalty is a psychological condition in which an employee is willing to make sacrifices, obey all the rules, and conditions in which the employee feels himself or herself bound by the company. So that the employee will work as much as possible not only for himself but for the progress of his company. Indicator employees' loyalty are: compliance with regulations, responsibility to the company, willingness to corporate, sense of belonging the company, interpersonal relationship, and loving the job (Sukawati and Suwandana 2021).

\section{Motivation}

Motivation is a process of giving encouragement to subordinates so that subordinates can work in line with the given limits in order to achieve organizational goals optimally (Sulistiyani 2018). Motivation is also referred to as a driver, desire, supporter or need that can make a person excited and motivated to reduce and fulfill one's own impulses, so that they can act and act in certain ways that will lead to an optimal direction. (Jufrizen 2017). Thus, Work motivation is given to employees so that they can work more optimally so that company goals can be achieved. Indicator of motivation are: physiological needs, safety and security needs, affiliation or acceptance needs, esteem or status needs, self-actualization Abraham Maslow in (Mangkunegara 2017).

\section{Working Environment}

According to Sedarmayanti (2017) working environment is a place for employees in which there are several supporting facilities to achieve company goals in accordance with the company's vision and mission. Sunyoto (2012) said that "Working environment is everything that is around the workers and that can affect them in carrying out the tasks assigned, such as cleanliness, music, lighting, and others." Thus, working environment is anything about the place where employees do their job include building and the work atmosphere that directly or indirectly affect employees' work. Indicator of working environment according to Sedarmayanti in (Sulistiawan et al. 2018) are: lighting, air circulation, noise, work safety, employees' relationship.

\section{Career Development}

Career management is the process by an organization to selects, assesses, assigns, and develops its employees to provide a pool of competent people to meet future needs (Shaputra and Hendriani 2015). Career planning helps employees to be more motivated to do their job as much as possible in order to get promotions from superiors. Robbins in (Wicaksono and Bieantri 2014), in career development opportunities, cooperation from both parties is needed, both from the company and from the employee side. Career development is future plan about career for employees that can they get as a reward for their work. Career development can be implied as education or training for employees' self-development. Indicator of career development Siagian (2012) are: fair treatment in career, superiors' concern, information about promotion, interest to be promotes, satisfaction level. 


\section{Relationship Between Motivation and Employees' Loyalty}

According to Hasibuan (2014), motivation is about how to encourage the passion of subordinates, so that they are willing to work hard by giving all the abilities and skills to realize the company's goals. A high level of effort to get the best results will lead to profitable loyalty results which is give benefits for the organization. Work motivation is the driving force or impetus in a person to want to behave and work diligently and well in accordance with the duties and obligations that have been given to him (Kadarisman 2017).

Hasibuan (2012) also stated that the purpose of work motivation is to maintain and increase employee loyalty. The research conducted by Sari (2018) mentioned that Employee's motivation significantly influences loyalty and company's advantage. In line with that the research conducted by Musnadi (2018) proved that work motivation had a positive and significant effect to employees' loyalty. From those theories, motivation that provide by the company will drive employees become loyal to the company. Employees who feel motivated will love their job and carry out their work seriously. Work motivation will foster the desire of employees to stay and survive to develop the company. Thus hypothesis 1 can be formulated as follows:

Ha1: Motivation influence employees' loyalty

\section{Relationship Between Working Environment and Employees' Loyalty}

Sarwoto (2017) states that working environment is a place where an employee works including physical and non-physical environments that can affect morale in carrying out work. According to Leblebici (2012), those who work in an inconvenient environment will most probably engage with low performance and end up with occupational issues such as absenteeism. A comfortable and appropriate working environment will encourage employees to work as well as possible, it will expedite the company's production process (Ramadhani 2016).

Many researchers have shown that employees prefer a safe and comfortable working environment. The research by Mandala and Astika (2019) said that employees will have a high loyalty if the employee has a comfortable working environment. (Al-Anzi 2009) mentioned in his study that due to the trend of working environment that creates positive outcome, most organizations face new a challenge to generate a working environment that attracts, maintains, and motivates the workforce. Working environment can have a positive or negative impact on employee productivity. Company must create a positive working environment and provide employees' need when they are doing their job so the employees will feel satisfied and tend to stay with the company. This means that the environment of the workplace has to be where the employees enjoy and increase productivity and create loyalty towards the organization. Thus hypothesis 2 can be formulated as follows:

Ha2: Working environment influence employees' loyalty.

\section{Relationship Between Career Development and Employees' Loyalty}

Career development is a series of activity or the ongoing process of developing one's career and a lifetime process of managing your organization's employees (Samat et al. 2020). Few companies plan and develop employee careers with clear, measurable bases and considerations. Career development is certainly something that every employee wants because generally, the higher a position is, the more prosperous their lives will be (Susita et al. 2020). Lack of career development and opportunities for promotion were key aspects associated with employee turnover (Ineson and Berechet 2011), indicating poor employee loyalty. According to research conducted by (Utami and Dwiatmadja 2020) that career development proved to have an influence on employee work loyalty because employees think that loyalty to the company needs to be carried out in proportion to the work expended and rewarded with career advancement in employees. Also the research by Majid et al. (2017) also stated that career development had significant positive correlations employees' loyalty.

A clear career planning will make employees feel that the company already understands their career needs. Every employee will definitely consider on how much the company supports themselves to develop and develop their careers. In addition, career development can also be assessed as a company award for the hard work that has been done by its employees. Many employees resign because they are dissatisfied with the position given by the company or it's hard for them to get promotion. Career development make employees feel valued so they become loyal to the company. Thus hypothesis 3 can be formulated as follows:

Ha3: Career Development influence employees' loyalty 


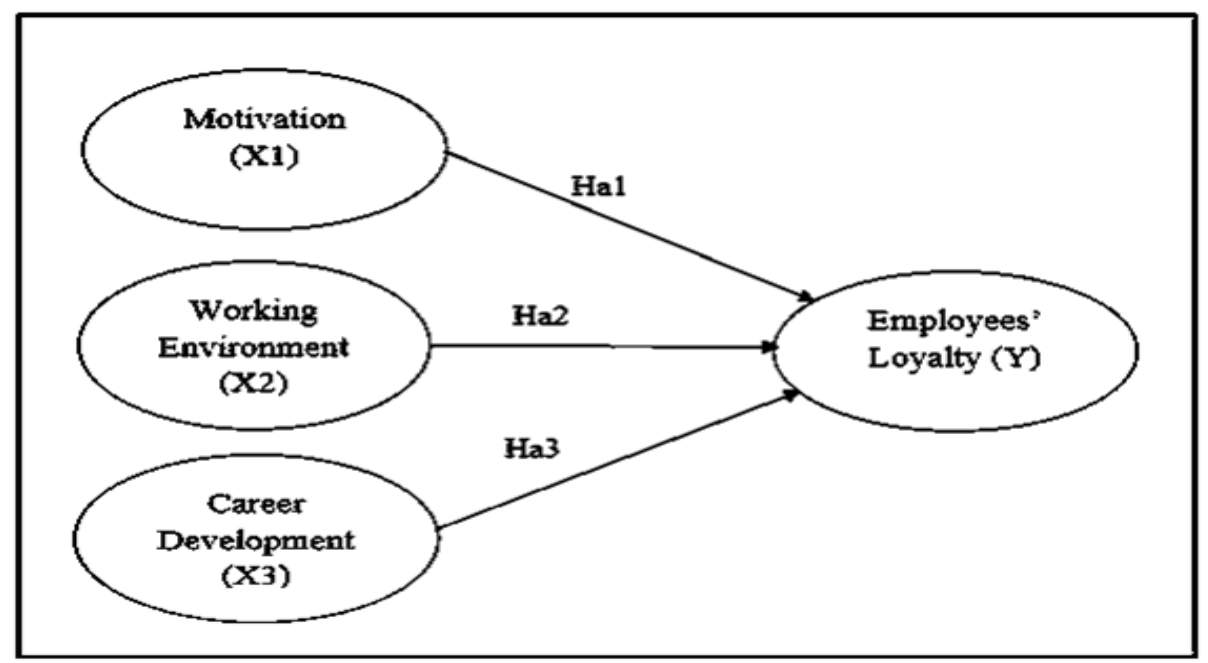

The Influence of Motivation, Working

Environment and Career

Development Toward Employees' Loyalty

Figure 1.

Theoretical Framework

\section{METHODOLOGY}

\section{Population and Sample}

The population in this study are all employees of PT Tawada Healthcare Semarang who are 35 employees. In this study, the researcher used total sampling or census. The sample in this study are all of PT Tawada Healthcare Semarang who are 35 employees.

The data collection method that use in this research are questionnaire, literature review, and interview. The data measurement technique in this study is using an interval scale. The interval scale that used in this study is agree-disagree scale by developing statements that produce agree-disagree answers in various ranges of values from 1-10.

The data analysis method in this research is multiple regression analysis, using program IBM statistic SPSS 24. The method that used are descriptive analysis, instrument test thet contains of validity test and reliability test, classic assumption test that contains of normality test, multicollinearity test, and heterocedasticity test, multiple linear regression, and goodness of fit test that contains of $\mathrm{f}$-test, t-test, coefficient determination test.

\section{RESULTS AND DISCUSSION}

\section{Respondents' Characteristic}

35 employees of PT Tawada Healthcare Semarang Branch are divided into several characteristics. Characteristics by gender, male employees are more dominant with a percentage of $57.1 \%$. According to age, employees in the age range of 21-40 years are the most numerous with a percentage of $80 \%$. According to the latest education, employees with bachelor's degrees are the most with a percentage of 51.4\%. And according to the length of work, employees with a length of work between 1,01 Years - 4,5 Years are the most with a percentage of $51.4 \%$.

\section{Descriptive Analysis}

Scoring of variables is done using a questionnaire with a semantic difference scale in the range of 1-10 which produces interval data. Using the three box method, the range is $90(100-10=90)$ divided into 3 will produce a range of 30 which will be used on the basis of the index value interpretation, are: low interpretation, medium interpretation, and high interpretation.

\section{Instrument Test}

According to the results of the validity test that all items in the questionnaire have value above 0.05 which is indicate that all question items in independent and dependent variable are valid.

The result of Reliability test are motivation, working environment, career development and employee's loyalty variables are reliable because the Cronbach's Alpha value has exceeded the alpha guideline used, which is 0.6 . 


\section{Classic Assumption Tests}

Before carrying out the goodness of fit test, a classic assumption test is carried out which aims to provide certainty that the regression equation obtained has accuracy in estimation, is unbiased, and consistent. Classic assumption test consists of multicollinearity test, heteroscedasticity test, and normality test. The result of multicollinearity test shows that the tolerance value for all independent variables is greater than 0.10.Meanwhile, the VIF value for all independent variables is less than 10.00. So referring to the basis of decision making in the multicollinearity test, it can be concluded that there are no symptoms of multicollinearity among the independent variables. The result of heteroscedasticity test shows that the point distribution did not form a particular pattern. The points also spread at random areas both above and below zero (0) on Y axis. So, it can be concluded that heteroscedasticity did not occur in this analysis. In other words, this model is homoscedasticity. The result of normality test is the sig value is $0.810>0.05$, then the data is normally distributed.

\section{Multiple Linear Regression}

The analytical method used in this study is multiple linear regression analysis using statistical test tools IBM SPSS 20.0. The variables studied are Motivation, Working Environment, and Career Development as independent variables and Employees' Loyalty as the dependent variable. The result of multiple linear regression analysis are:

Table 2.

Multiple Linear Regression Analysis

\section{Table 3.}

Determination Test

Table 4.

T Test

\begin{tabular}{|c|c|c|c|c|}
\hline \multirow{2}{*}{\multicolumn{2}{|c|}{ Model }} & \multicolumn{2}{c|}{ Unstandardized Coefficient } & $\begin{array}{c}\text { Unstandardized } \\
\text { Coefficient }\end{array}$ \\
\cline { 2 - 4 } \multicolumn{2}{|c|}{} & Beta & SE & Beta \\
\hline 1 & (Constant) & 13.521 & 7.455 & \\
\hline & Motivation (M) & .327 & .161 & .308 \\
\hline & Working Environment (WK) & .427 & .120 & .408 \\
\hline & Career Development (CD) & .284 & .133 & .276 \\
\hline
\end{tabular}

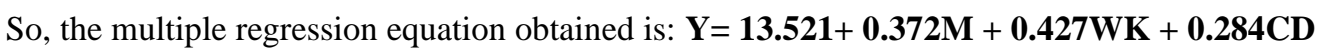

\section{Goodness of Fit Multiple Regression Equation}

\section{Determination Correlation Test}

The coefficient of determination is used to measure the ability of the model to explain the variation of the dependent Ghozali (2018).

\begin{tabular}{|c|c|c|c|c|}
\hline Model & $\mathrm{R}$ & R Square & Adjusted R Square & SE \\
\hline 1 & .911 & .830 & .813 & 4.322 \\
\hline
\end{tabular}

The result of the test is the value of adjusted $\mathrm{R} 2$ is 0,813 which means that the variability of the dependent variable (employees' loyalty) can be explained by the variability of the independent variable (motivation, working environment, and career development) of $81.3 \%$. While the remaining $18.7 \%$ is explained by other variables not included in the regression model.

\section{T-Test}

The t-test is known as a partial test, which is to test how the influence of each independent variable individually explain the dependent variable (Ghozali 2018). The criteria of decision making in the hypothesis testing are as follows: If probability $>\alpha 0.05$, so Ho is accepted. Opposite from it, if probability $<\alpha 0.05$, so Ho is rejected

\begin{tabular}{|c|c|c|}
\hline Model & $\mathrm{t}$ & Sig. \\
\hline (Constant) & 1.814 & .079 \\
\hline Motivation & 2.305 & .028 \\
\hline Working Environment & 2.323 & .002 \\
\hline Career Development & 2.133 & .041 \\
\hline
\end{tabular}


The result of the test are: The sig. value of Motivation is 0.028 which is below 0.05 . Therefore, H01 is rejected and Hal is accepted. Thus, it can be concluded that Motivation has significant effect on Employees' Loyalty. The sig. value of Working Environment is 0.002 which is less than 0.05 . It means H02 is rejected and Ha2 is accepted, it can be said that Working Environment has significant effect on Employees' Loyalty. The sig. value of Career Development is 0.041 which is below 0.05. It indicates that H03 is rejected and Ha3 is accepted. Thus the conclusion is Career Development has significant effect on Employees' Loyalty.

\section{Discussion}

\section{The Relation between Motivation and Employees' Loyalty}

Following the results of the test, motivation is determined to have significant effect toward employees' loyalty. Having the sig. value 0.028 which is less than 0.05 bring the conclusion of rejecting H01. Motivation is increasingly important because the company's resource management is to delegate tasks to employees to be completed properly and together to achieve the goals that have been set collectively. Good personal characteristics. of an employee are not only desired by the company but also abilities, skills and skills are important factors that can help companies achieve optimal work performance. If an employee's sense of loyalty or loyalty is high, usually the employee is willing to do the work assigned to them more than they should. The research conducted by Citra (2019) stated that motivation had an influence on employee loyalty

\section{The Relation between Working Environment and Employees' Loyalty}

The result of the test on working environment toward employee loyalty shows that it have significant effect. The outcomes shows a significant value of working environment variable of 0.002 is less than 0.05 . Hence, it comes to a conclusion that $\mathrm{Ha} 2$ is accepted and $\mathrm{H} 02$ is rejected. The more company pay attention to working environment, the more employees will be loyal. Suitability of the working environment can be seen as the consequences in the long term. Furthermore, environments poor working and labour can demand more time and do not support obtaining plan efficient working system. The research by Susita et al. (2020) also proved that working environment have a significant effect toward employees' loyalty. In addition, based on the opinion of Andrews in Putra and Sriathi (2019), it states that a good work environment will lead to comfort in carrying out daily work activities. A comfort work environment will create good atmosphere to work and attract them to become loyal to the company

\section{The Relation between Career Development and Employees' Loyalty}

The variable career development has a sig. value 0.041 which is less than 0.05 . That outcomes indicate that Ha3 is accepted and H03 is rejected which mean that employees' loyalty is influenced by career development. The factor of placing the right individual into a position by looking at his abilities is also considered important. A company that has started implementing the right placement and started from the recruitment period, is considered to be able to manage human resources more directed. Further explanation is related to Samat et al. (2020) stated that employees' loyalty also influenced by career development. Hedge and Rineer (2017), a strong career development and progression system will recognize that careers are nether static nor developed in a vacuum. Workers' decisions about their career moves are determined by current skills and interests, as well as previous work histories and long-term plans. Career development as a factor to predict loyalty.

\section{CONCLUSION}

Motivation, working environment, and career development have a positive and significant effect toward employees' loyalty both partially. Working environment has a dominant influence in increasing employee loyalty. Furthermore, the determination coefficient result was 0,813 which means employees' loyalty can be explained by motivation, working environment, and career development as much $81.3 \%$. The remaining $18.7 \%$ was explained by other factors that not explained in this research.

According to T-Test, it was found that the resulting regression equation function can be used to estimate the changes in employees' loyalty at PT Tawada Healthcare Semarang.

Based on T-Test result, it showed that partially all of the independent variables influenced employees' loyalty in PT Tawada Healthcare Semarang. Motivation had a positive and significant influence toward employees' loyalty. Working environment had positive and significant influence toward employees' loyalty. Also, career development had a positive and significant influence toward employees' loyalty.

This study only examine motivation, working environment, and career development as independent variable. There are still many variables that also can affect employees' loyalty that can be used for future studies. This study only used sample data at PT Tawada Healthcare Semarang Branch which is has 35 employees. Future research needs to be carried out on a larger scale, such as all branch office of PT Tawada Healthcare in Indonesia or other medical device distributor company.
The Influence of Motivation, Working

Environment and Career

Development Toward Employees' Loyalty 
Al-Anzi, N. M. (2009). "Workplace environment and its impact on employee performance." Project Management Department, Retrieved August 8: 2011.

Allen, N. J. and D. B. Grisaffe (2001). "Employee commitment to the organization and customer reactions: Mapping the linkages." Human Resource Management Review 11(3): 209-236.

Ardana, I. K., et al. (2012). Manajemen Sumber Daya Manusia. Yogyakarta, Graha Ilmu.

Becker, T. E., et al. (1995). "The multidimensional view of commitment and the theory of reasoned action: A comparative evaluation." Journal of Management 21(4): 617-638.

Citra, L. M. (2019). "Pengaruh Kepemimpinan, Kepuasan Kerja Dan Motivasi Kerja Terhadap Loyalitas Karyawan." Maneggio: Jurnal Ilmiah Magister Manajemen 2(2): 214-225.

Dubrin, A. J. (2015). Human Relations Interpersonal Job Oriented Skills. United States, Pearson Education.

Ghozali, I. (2018). Aplikasi Analisis Multivariate Dengan Program IBM SPSS 25. Semarang, Universitas Diponegoro.

Hasibuan, M. S. (2012). Manajemen Sumber Daya Manusia. Jakarta, PT Bumi Aksara.

Hasibuan, M. S. (2014). Manajemen Sumber Daya Manusia. Jakarta, Bumi Aksara.

Ineson, E. M. and G. Berechet (2011). "Employee loyalty in hotels: Romanian experiences." Journal of human resources in hospitality tourism 10(2): 129-149.

Jufrizen, J. (2017). "Pengaruh kemampuan dan motivasi terhadap kinerja perawat." Jurnal Riset Sains Manajemen $1(1): 27-34$.

Juliarti, P. A. D., et al. (2018). "Effect of Compensation and Work Environment on Employee Performance with Employee Job Satisfaction as an Intervening Variable." International Journal of Contemporary Research Review 9(03): 20553-20562.

Kadarisman (2017). Manajemen Pengembangan Sumber Daya Manusia. Jakarta, PT RajaGrafindo Persada.

Kurniawan, A. (2014). Metode riset untuk ekonomi dan bisnis. Bandung, Alfabeta.

Leblebici, D. (2012). "Impact of workplace quality on employee's productivity: case study of a bank in Turkey." Journal of Business Economics Finance 1(1): 38-49.

Majid, M. A. A., et al. (2017). "Career Development, Job Security and Employee Loyalty at a Luxury Resort in Terengganu, Malaysia." International Journal of Academic Research in Business Social Sciences 7(10): 667-674.

Mandala, I. and I. B. P. Astika (2019). "Effect of work environment, quality of system and work culture on satisfaction of accounting information system user." International Research Journal of Management, IT Social Sciences 6(4): 37-43.

Mangkunegara, A. P. (2017). Manajemen Sumber Daya Manusia Perusahaan (Cetakan Kesebelas ). Bandung, PT Remaja Rosdakarya.

Musnadi, S. (2018). "Pengaruh Lingkungan Kerja, Kompensasi Dan Motivasi Terhadap Kepuasan Kerja Serta Dampaknya Terhadap Loyalitas Kerja Pegawai Rutan Di Provinsi Aceh (Studi Kasus Pada Rutan Klas Ii B Banda Aceh Dan Rutan Klas Ii B Jantho." Jurnal Magister Manajemen 2(1): 88-98.

Onsardi, T. A., Moch Asmawi (2017). "The Effect Of Compensation, Empowerment, And Job Satisfaction On Employee Loyalty." International Journal of Scientific Research and Management 5(12): 7590-7599.

Purnamasari, N. P. D. and D. K. Sintaasih (2019). "Pengaruh Pengembangan Karir, Kompensasi, Dan Iklim Organisasi Terhadap Loyalitas Karyawan." E-Jurnal Manajemen 8(9): 5762-5782.

Ramadhani, F. (2016). "Faculty of Economics Riau University." JOMFekom 4(1): 1960-1970.

Samat, M. F., et al. (2020). "The Relationship Between Career Development, Compensation, Job Security, Work Environment And Employee Loyalty." e-Academia Journal 9(1).

Sari, E. T. (2018). "Motivation And Satisfaction Towards Employees'loyalty To Achieve Company's Advantage." JMBI UNSRAT . 4(1).

Sarwoto (2017). Dasar-Dasar Organisasi dan Manajemen. Jakarta, Ghalia Indonesia.

Sazkaya, M. K. and Y. E. Dede (2018). "The Mediating Role of Employee Loyalty between Employee Empowerment and Employee Innovative Behavior: A Study from Teknopark Istanbul." Journal of the Faculty of Economics and Administrative Sciences 8(1): 55-82.

Sedarmayanti (2011). Tata Kerja dan Produktivitas Kerja. Bandung, Mandar Maju.

Sedarmayanti (2017). Manajemen Sumber Daya Manusia Reformasi Birokrasi dan Manajemen Pegawai Negeri Sipil. Bandung, Refika Aditama.

Shaputra, A. R. and S. Hendriani (2015). "Pengaruh kompetensi, komitmen dan pengembangan karir terhadap kinerja karyawan PT. Bank Rakyat Indonesia (Persero) Kantor Wilayah Pekanbaru." Jurnal Tepak Manajemen Bisnis 7(1): 1-17. 
Siagian, S. (2012). Manajemen Sumber Daya Manusia. Jakarta, Bumi Aksara.

Sukawati, T. B. W. and I. G. M. Suwandana (2021). "Effect of Physical Work Environment, Workload, and Compensation on Employee Loyalty at Visesa Ubud Resort." American Journal of Humanities and Social Sciences Research (AJHSSR) 5(2): 399-408.

Sulistiawan, D., et al. (2018). "Pengaruh budaya organisasi dan lingkungan kerja terhadap kinerja pegawai." Jurnal Ekonomi dan Manajemen 14(2): 61-69.

Susita, D., et al. (2020). "The Effect of Career Development and Work Environment on Employee Loyalty with Work Satisfaction as Intervening Variables." The International Journal of Social Sciences World 2(2): 20-31.

Utami, V. A. V. W. R. and C. Dwiatmadja (2020). "Pengaruh Pengembangan Karir, Motivasi Kerja dan Pemberian Kompensasi terhadap Loyalitas Kerja Karyawan (Studi Kasus pada Karyawan PT. Tribun Berita Online)." International Journal of Social Science Business 4(2): 267-275.

The Influence of Motivation, Working

Environment and Career

Development Toward Employees' Loyalty 